\title{
IMPLEMENTASI LESSON STUDY UNTUK MENUMBUHKAN KEAKTIFAN BELAJAR DAN KERJASAMA MAHASISWA
}

\author{
Marfi Ario' \\ Universitas Pasir Pengaraian \\ marfi.ario.92@gmail.com
}

\begin{abstract}
ABSTRAK Tujuan pembelajaran terdiri dari tiga aspek, diantaranya yaitu aspek afektif. Penelitian ini bermaksud untuk menumbuhkan dua diantara sekian banyak kemampuan afektif yaitu kerjasama dan keaktifan belajar mahasiswa. Pembelajaran berkualitas dari seorang dosen dituntut untuk bisa mencapai tujuan tersebut. Untuk membentuk pembelajaran berkualitas, seorang dosen dapat berkolaborasi dengan dosen yang lain. Atas dasar hal itu, penelitian ini dilaksanakan dengan menerapkan lesson study. Penelitian ini merupakan penelitian kualitatif deskriptif yang menjelaskan implementasi lesson study dalam menumbuhkan kemampuan kerjasama dan keaktifan belajar mahasiswa. Lesson study dilaksanakan dalam dua siklus dengan masing-masing terdiri dari tahap plan, do, see. Subyek penelitian adalah mahasiswa pendidikan matematika offering I Universitas Negeri Malang sebanyak 27 orang. Data yang dikumpulkan adalah data tentang kerjasama dan keaktifan belajar mahasiswa. Data dikumpulkan melalui observasi, diskusi, dan dokumentasi. Data dianalisis dengan menghitung skor kerjasama dan keaktifan belajar mahasiswa. Hasil penelitian menunjukkan bahwa pelaksanaan lesson study berjalan dengan baik dan mahasiswa memiliki kemampuan kerjasama dan keaktifan belajar yang sebagian besar masuk pada kategori sangat baik.
\end{abstract}

Kata-kata Kunci : lesson study, kerjasama, keaktifan belajar.

\section{PENDAHULUAN}

Salah satu yang mempengaruhi kemajuan suatu bangsa adalah kualitas pendidikannya (Ario, 2017). Kualitas pendidikan sendiri dipengaruhi oleh banyak hal, salah satunya oleh tenaga pendidik. Tenaga pendidik dapat berupa seorang guru atau seorang dosen. Zubaidah (2010) menyatakan guru merupakan penentu keberhasilan pendidikan melalui kinerjanya pada tataran institusional dan eksperiensial, sehingga upaya meningkatkan mutu pendidikan harus dimulai dari aspek guru dan tenaga kependidikan lainnya.

Menurut UU Nomor 14 Tahun 2005 seorang guru harus memiliki empat kompetensi, yaitu kompetensi pedagogik, kepribadian, profesional, dan sosial. Keempat kompetensi tersebut dapat terbentuk dengan berbagai cara. Salah satu sarana yang dapat menumbuhkan keempat kompetensi tersebut, khususnya kompetensi profesional dan pedagogik seorang guru (dosen) adalah lesson study. Melalui lesson study, sekelompok guru dapat saling berbagi pengalaman tentang materi pelajaran (profesional) dan juga cara mengajar (pedagogik). Selain itu kolaborasi dan kerjasama yang dilakukan pada pelaksanaan lesson study secara tidak 
langsung juga akan menumbuhkan kompetensi sosial dan kepribadian seorang guru (dosen). Hal ini karena pada pelaksanaan lesson study setiap peserta tidak boleh merasa superior (merasa paling pintar) atau imperior (merasa rendah diri) tetapi semua peserta kegiatan lesson study harus diniatkan untuk saling belajar (Zubaidah, 2010). Sikap ini merupakan bagian dari kompetensi kepribadian dan sosial seorang guru (dosen).

Lesson study adalah proses terstruktur dimana guru-guru bekerja bersama untuk memformulasikan solusi dari hambatan yang dihadapi pada proses belajar dan mengajar (Maths Development Team, 2017). Pada lesson study, guru-guru berkolaborasi memilih sebuah topik dan perencanaan serta mempersiapkan pembelajaran (yang disebut dengan research lesson), salah seorang guru menerapkan research lesson dan yang lain mengobservasi siswa di kelas, lalu para guru berdiskusi tentang hasil observasi mereka (Coenders\&Verhoef, 2018). Sementara itu, Kemenristekdikti (2018) menyatakan bahwa lesson study adalah suatu model pembinaan profesi pendidik melalui pengkajian pembelajaran secara kolaboratif dan berkelanjutan berlandaskan prinsip-prinsip kolegialitas dan mutual learning untuk meningkatkan kualitas pembelajaran dan membangung learning community. Lebih lanjut, kemerinstekdikti (2018) menyatakan:

"Kegiatan lesson study sangat potensial untuk mendorong banyak pihak melakukan hal yang terbaik dalam meningkatkan kualitas perkuliahan dan mampu meningkatkan motivasi berprestasi pada mahasiswa. Melalui kegiatan lesson study, dosen juga termovasi untuk melakukan persiapan yang lebih baik dibanding sebelumnya. Hal ini, secara tidak langsung mereka telah melakukan inovasi dalam pembelajaran. Mereka mulai tertarik untuk mencoba menerapkan pengalaman berharga dari pembelajaran dosen lain (lesson learn) pada kelas yang menjadi tanggungjawabnya".

Berdasarkan pemaparan tentang lesson study maka dapat ditarik kesimpulan bahwa sebenarnnya pelaksanaan lesson study ditujukan untuk mencapai tujuan pembelajaran dikelas dan sekaligus menyelesaikan persoalan-persoalan yang ditemui guru di kelas. Persoalan-persoalan tersebut dibahas bersama tim untuk dicarikan solusinya. Metode, strategi, atau model pembelajaran apa yang paling efektif untuk mengatasi persoalan yang dihadapi untuk mencapai tujuan pembelajaran.

Tujuan pembelajaran tidak hanya dimaksudkan pada kemampuan-kemampuan kognitif, tetapi juga pada aspek afektif (Ario, 2015). Banyak aspek afektif yang harus dimiliki mahasiswa, diantaranya yaitu keaktifan belajar dan kerjasama. Keaktifan belajar adalah kegiatan dengan menggunakan akal, pendengaran, penglihatan, dan peraba untuk memfokuskan diri pada materi pelajaran (Yahya,dkk 2013). Keaktifan siswa terlihat dari merespon pertanyaan atau perintah guru, mendengarkan dan memperhatikan penjelasan guru, berani mengemukakan pendapat, dan aktif mengerjakan soal yang diberikan guru (Khasanah, 2016). Keaktifan belajar merupakan hal yang sangat penting pada pembelajaran masa sekarang. Pembelajaran dimasa modern ini justru menuntut siswa yang lebih aktif untuk belajar dibanding guru mengajar. Hal ini kita kenal dengan sebutan students-center. 
Kerjasama adalah bekerja bersama untuk mencapai tujuan yang diinginkan bersama (Slavin, 2012). Kerjasama merupakan suatu kemampuan afektif yang penting bagi mahasiswa baik ketika mereka sedang dalam proses pembelajaran di kelas, maupun ketika mereka berada di luar kelas. Saat di kelas, kerjasama diperlukan untuk membuat mahasiswa saling membantu memahami materi yang sedang dijelaskan. Melalui kerjasama yang baik, mahasiswa yang pintar dapat mengajari temannya yang belum mengerti. Melalui kerjasama, tugas-tugas yang diberikan dosen dapat diselesaikan dengan baik dan lebih cepat oleh mahasiswa. Membangun kerjasama antar mahasiswa adalah penting untuk dilakukan oleh dosen. Selain untuk tujuan di dalam kelas, kerjasama juga penting dalam menjalankan kehidupan sehari-hari. Kekompleksan permasalahan dalam kehidupan menuntut adanya kerjasama dari berbagai pihak dengan beragam keahlian.

Untuk dapat menumbuhkan keaktifan belajar maupun kerjasama antar mahasiswa maka dosen harus melakukan suatu proses pembelajaran yang tepat. Proses pembelajaran yang mampu membuat mahasiswa aktif dan bekerjasama dalam menyelesaikan tugas-tugas yang diberikan. Salah satu pendekatan yang dapat diterapkan untuk menumbuhkan keaktifan belajar mahasiswa adalah dengan menerapkan pendekatan konstruktivisme model kooperatif. Pendekatan ini memberikan kesempatan pada mahasiswa untuk lebih aktif dan kreatif menemukan ide-ide, konsep-konsep baru berdasarkan pengalaman dan penemuannya sendiri (Wagiran, 2006). Barkley (2012) menyatakan bahwa jika pengajar menginginkan peserta didiknya untuk bekerja sama menyelesaikan tugas bersama, berbagi informasi, dan saling mendukung maka pembelajaran kooperatif lazim untuk dipraktekkan di dalam kelas. Salah satu pembelajaran yang dapat mengajarkan keterampilan bekerjasama adalah pembelajaran menggunakan model kooperatif. Berdasarkan penjelasan tersebut, dapat dikatakan bahwa pembelajaran berkelompok akan mampu menumbuhkan keaktifan belajar maupun kerjasama antar mahasiswa.

Penelitian ini bertujuan untuk mendeskripsikan pelaksanaan lesson study untuk menumbuhkan keaktifan belajar dan kerjasama antar mahasiswa. Kegiatan lesson study ini peneliti lakukan dalam program magang dosen oleh kemeristekdikti yang dilaksanakan di Universitas Negeri Malang. Oleh karena itu tim lesson study ini terdiri dari peneliti sendiri dan rekan-rekan dosen magang lainnya dari berbagai universitas di Indonesia.

\section{METODE PENELITIAN}

Penelitian ini menggunakan pendekatan kualitatif deskriptif. Penelitian ini bermaksud mendeskripsikan pelaksanaan lesson study dalam rangka menumbuhkan kemampuan kerjasama dan keaktifan belajar mahasiswa. Subyek penelitian ini adalah mahasiswa semester I Program Studi Pendidikan Matematika offering I angkatan 2018 Universitas Negeri Malang. Data yang dikumpulkan adalah kemampuan kerjasama dan keaktifan belajar mahasiswa. Data dikumpulkan melalui observasi, diskusi, dan dokumentasi foto dan video. Analisis data dilakukan dengan menghitung skor kemampuan kerjasama dan keaktifan belajar mahasiswa yang diisi oleh observer selama pembelajaran serta 
mendeskripsikan dan menyimpulkan hasil diskusi dan dokumentasi. Pada proses penilaian kerjasama dan keaktifan belajar mahasiswa, setiap observer hanya mengamati sekitar 8 mahasiswa berdasarkan rambu-rambu penilaian yang ada pada lembar observasi. Hal ini dimaksudkan agar pengamatan lebih terfokus sehingga benar-benar menggambarkan kondisi yang sebenarnya.

Pelaksanaan lesson study dilakukan dalam dua siklus. Penulis menjadi dosen model selama dua siklus tersebut sementara rekan-rekan dosen lain sebagai observer. Setiap siklus terdiri dari tahapan plan, do, dan see. Tahapan plan dilaksanakan secara fleksible dan diperbaharui sebelum tahap do dilaksanakan.

Siklus pertama kegiatan do dan see dilaksanakan pada tanggal 14 September 2018. Siklus pertama ini membahas materi tentang fungsi naik, fungsi turun, dan fungsi konstan serta aljabar fungsi. Observer pada siklus satu ini adalah Sugiantoro, S.Sos., M.Pd; Ilmiyati Rahmy Jasril, S.Pd., M.Pd.T; M. Zainul Asror, S.Pd., M.A; dan Annajmi, M.Pd.

Siklus kedua kegiatan do dan see dilaksanakan pada tanggal 21 September 2018. Siklus kedua ini membahas materi tentang komposisi fungsi dan kesimetrisan fungsi. Observer pada siklus satu ini adalah Dr. Eddy Sutadji, M.Pd; Sugiantoro, S.Sos., M.Pd; Ilmiyati Rahmy Jasril, S.Pd., M.Pd.T; M. Zainul Asror, S.Pd., M.A; dan Annajmi, M.Pd.

\section{HASIL DAN PEMBAHASAN}

Kemampuan kerjasama dan keaktifan belajar merupakan aspek afektif yang penting untuk dimiliki oleh setiap mahasiswa. Untuk menumbuhkan kedua kemampuan tersebut, penulis dan tim lesson study melaksanakan pembelajaran yang terpusat kepada mahasiswa. Pembelajaran dilaksanakan dengan metode diskusi kelompok dan diikuti dengan turnamen diakhir diskusi. Proses pembelajaran ini merupakan bagian implementasi lesson study. Lessson study pada penelitian ini dilakukan sebanyak dua siklus. Masing-masing siklus terdiri dari tahapan plan, do, see. Berikut ini disajikan paparan pada setiap siklus.

\section{Siklus I}

Tahapan plan pada siklus I dilaksanakan pada tanggal 4 september 2018. Beberapa catatan penting pada tahapan plan adalah sebagai berikut.

a. Pembelajaran sebaiknya dipusatkan kepada mahasiswa. Aktifitas belajar harus lebih banyak dilakukan oleh mahasiswa daripada penjelasan dari dosen. Pembelajaran harus memfasilitasi mahasiswa untuk membangun sendiri pengetahuannya. Awalnya pembelajaran direncanakan dengan penjelasan materi oleh dosen, lalu latihan secara berkelompok oleh mahasiswa. Tapi untuk membuat mahasiswa terlibat lebih banyak dalam pembelajaran, maka pembelajaran diganti dengan kegiatan: mahasiswa mempelajari sendiri materi perkuliahan dan dibimbing oleh dosen jika mengalami kesulitan, lalu diadakan turnamen untuk memacu mahasiswa dalam memahami materi.

b. Dosen harus mampu menyiapkan pertanyaan-pertanyaan atau soal yang mampu menumbuhkan kemampuan berpikir kritis mahasiswa. Atas dasar ini, soal-soal yang dimunculkan pada slide dan Lembar Kerja Mahasiswa (LKM) harus disusun sedemikian rupa sehingga lebih mengutamakan pemahaman konsep daripada kemampuan prosedural. 
c. Pembelajaran harus dirancang semenarik mungkin dan tidak membosankan. Hal ini dapat dilakukan dengan melaksanakan pembelajaran berkelompok yang tidak didominasi ceramah oleh dosen.

d. Materi yang disajikan harus disesuaikan dengan alokasi waktu dan model pembelajaran yang digunakan. Karena mengedepankan aktifitas belajar mahasiswa maka memerlukan waktu yang lebih lama dibandingkan pembelajaran konvensional dengan metode ceramah dari dosen. Atas dasar ini maka materi yang awalnya terdiri dari 4 topik pembelajaran diganti menjadi 3 topik pembelajaran.

e. Dosen harus mampu mengendalikan kelas dan waktu saat pelaksanaan do, karena seringkali saat berkelompok mahasiswa menghabiskan banyak waktu saat diskusi dan mengakibatkan tidak terlaksananya aktifitas belajar lain yang telah direncanakan.

f. Materi matematika merupakan materi yang abstrak. Perlu menjelaskan apa kegunaan atau aplikasi materi yang dipelajari dengan kehidupan sehari-hari. Atas dasar ini, pada tahap awal pembelajaran akan dijelaskan terlebih dahulu kegunaan materi dalam kehidupan.

Berdasarkan plan yang telah dibuat, dilaksanakan do pada tanggal 14 September 2018. Pelaksanaan pembelajaran dikelas dapat diringkas sebagai berikut. Pada kegiatan pendahuluan: dosen mengabsen mahasiswa, memberikan apersepsi, memotivasi mahasiswa dengan mengaitkan materi pelajaran dengan kehidupan sehari-hari, dan memberi pengantar tentang materi yang akan dipelajari. Pada kegiatan inti: mahasiswa belajar di kelompok masing-masing membahas materi sementara dosen memberikan bimbingan kepada semua kelompok yang mengalami kendala, perwakilan mahasiswa mempresentasikan hasil pekerjaan kelompoknya, melaksanakan turnamen antar kelompok dengan cara masingmasing kelompok mengutus satu orang secara bergantian sampai turnamen selesai. Pada kegiatan penutup: dosen dan mahasiswa menyimpulkan materi pelajaran, melaksanakan kuis.

Pada pelaksanaan do ini, selain dosen model (peneliti) terdapat juga empat orang observer yang melakukan pengamatan terhadap aktivitas belajar mahasiswa. Kepada setiap observer diberikan angket yang berisi hasil pengamatan tentang keaktifan belajar dan kerjasama mahasiswa.

Selesai melaksanakan kegiatan do, tim lesson study melaksanakan see pada hari yang sama. Tahap see dimaksudkan untuk mendiskusikan hasil pengamatan yang telah dilakukan oleh para observer. Berikut ini adalah hasil see yang diperoleh:

\section{a. Pelajaran Berharga (Lesson Learn)}

Kesuksesan pembelajaran di kelas diawali dengan kesuksesan dalam perencanaan. Pelaksanaan siklus pertama memberikan pengalaman nyata kepada semua anggota tim bahwa perencanaan sangat penting dalam suatu pembelajaran. Sesuatu yang sudah direncanakan dengan matang akan memberikan hasil yang lebih baik. Pada pelaksanaan siklus pertama ini, dosen model dan tim telah membuat perencanaan yang sangat baik. Hal ini ditandai dengan pembuatan instrumen atau perangkat pembelajaran yang lengkap. Mulai dari RPP, slide power point, LKM, soal latihan, soal turnamen, angket penilaian, 
lembar observasi, penomoran mahasiswa, dan sebagainya. Walaupun telah direncanakan dengan matang, pada pelaksanaannya tetap ada sesuatu yang tidak sesuai rencana. Hal ini terkait dengan ketersediaan waktu. Beberapa kegiatan harus diselesaikan dengan lebih cepat dari perencanaan. Kejadian ini memberikan pengalaman kepada tim bahwa dosen model harus juga siap untuk menjalankan rencana B jika ternyata terjadi perubahan kondisi di kelas. Namun secara umum perencanaan yang dilakukan dosen model dan tim pada siklus satu ini telah baik.

Pada tahap pelaksanaan pembelajaran di kelas, banyak sekali pelajaran yang dapat diambil oleh tim dan dosen model sendiri. Berdasarkan hasil observasi dan refleksi dari para observer dapat disimpulkan beberapa pelajaran berharga yang dapat diambil dari pelaksanaan tahap DO di kelas. Pertama, dosen model selama pembelajaran memberikan perhatian dan pendampingan yang merata kepada setiap mahasiswa. Hal ini penting untuk membuat semua mahasiswa merasa nyaman dan tidak ada pilih kasih oleh dosen. Kedua, dosen selalu memberikan support dan pujian kepada mahasiswa. Hal ini penting untuk terus memacu semangat mahasiswa dalam belajar dan memberikan komentar. Ketiga, pelaksanaan turnamen mampu meningkatkan keaktifan belajar mahasiswa. Kompetisi antar mahasiswa berhasil membuat mahasiswa berlomba-lomba memahami materi agar mampu memenangkan kompetisi. Keempat, contoh nyata penggunaan materi pelajaran terhadap kehidupan sehari-hari sangat penting dalam pembelajaran matematika. Hal ini terlihat pada saat dosen model menyajikan kegunaan materi, mahasiswa antusias memperhatikan dan termotivasi untuk mengikuti proses pembelajaran berikutnya. Kelima, pendampingan dari dosen selama diskusi diperlukan untuk membenarkan konsep mahasiswa. Keenam, dosen menunjuk mahasiswa yang pasif untuk tampil dan menjawab memberikan hasil yang baik terhadap mahasiswa tersebut. Mahasiswa yang pasif pada akhirnya menjadi aktif dan fokus pada pembelajaran.

\section{b. Catatan tentang kekurangan dan kelebihan dari RPP kegiatan yang dilaksanakan Dosen di kelasnya dikaitkan dengan hasil Lesson Study}

Terdapat kelebihan dan kekurangan dari RPP kegiatan yang telah dilaksanakan dosen model di kelas. Kelebihan dari RPP yang digunakan oleh dosen adalah berhasilnya dosen model dalam mengaktifkan mahasiswa untuk belajar. Konsep belajar yang mengedepankan kolaborasi antar mahasiswa dalam memahami materi membuat mahasiswa berhasil mencapai tujuan pembelajaran yang diinginkan. RPP yang digunakan adalah pembelajaran kolaboratif. Hal ini menumbuhkan kemampuan berkolaborasi antar mahasiswa. Selain itu pembelajaran dengan turnamen mampu membuat mahasiswa saling membantu untuk bisa menjawab soal-soal turnamen, karena hasil kelompok dipengaruhi oleh keberhasilan setiap anggotanya dalam menjawab soal turnamen.

Jika ditinjau dari dosen model sendiri, terdapat beberapa kelebihan dari dosen model saat pelaksanaan pembelajaran, yaitu: dosen model mampu memberikan pendampingan secara merata dan menyeluruh kepada semua mahasiswa; dosen model mampu membawa pembelajaran dengan cara santai dan banyak lelucon sehingga suasana kelas tidak terasa tegang; dosen model sering memberikan pujian kepada mahasiswa yang mau memberikan jawaban atau komentar 
sehingga mahasiswa termotivasi untuk terus mengikuti pembelajaran dengan baik; dosen model mampu membawa mahasiswa yang pasif menjadi aktif untuk belajar.

Selain kelebihan, terdapat juga kekurangan dari RPP yang digunakan oleh dosen model, yaitu pembelajaran yang mengedepankan aktivitas mahasiswa memerlukan waktu yang relatif lebih lama dibandingkan pembelajaran dengan metode ceramah. Pelaksanaan saat di kelas menunjukkan bahwa tidak semua materi dapat diselesaikan sebagaimana harusnya. Materi topik terakhir pada siklus satu harus diselesaikan dengan cara dosen menjelaskan materi. Hal ini karena tidak memungkinkan jika harus didiskusikan oleh mahasiswa mengingat waktu yang tinggal sedikit. Jika ditinjau dari dosen model sendiri, dosen model kurang mampu mengendalikan kegiatan kelas sehingga waktu diskusi kelompok melebihi waktu yang direncanakan.

Berikut ini disajikan hasil pengamatan observer tentang keaktifan belajar dan kerjasama mahasiswa.

Tabel 1. Skor Kerjasama dan Keaktifan Belajar Mahasiswa pada Siklus I

\begin{tabular}{cccccc}
\hline \multirow{2}{*}{ Aspek Afektif } & \multicolumn{4}{c}{ Banyak Mahasiswa yang Memperoleh Skor } & \multirow{2}{*}{ Total } \\
\cline { 2 - 5 } & 1 & 2 & 3 & 4 & \\
\hline Kerjasama & 0 & 2 & 10 & 15 & \multirow{2}{*}{27} \\
\hline Keaktifan Belajar & 0 & 2 & 6 & 19 & \\
\hline Keterangan Skor: & 1: Tidak Baik; & 2: Kurang Baik; & 3: Baik; 4: Sangat Baik
\end{tabular}

Berdasarkan Tabel 1 dapat dilihat bahwa sebagian besar mahasiswa memiliki skor 3 dan 4 pada masing-masing aspek yang dinilai. Hal ini bermakna bahwa keaktifan belajar dan kerjasama mahasiswa berada pada kategori Baik dan Sangat Baik.

\section{Siklus II}

Tahapan plan pada siklus II dilaksanakan pada tanggal 4 september 2018. Beberapa catatan penting pada tahapan plan adalah sebagai berikut.

a. Mengacu kepada pelaksanaan pembelajaran (do) pada siklus pertama, maka perlu pengurangan kegiatan pada siklus kedua. Pada siklus pertama dosen kekurangan waktu sehingga tahap 'latihan' tidak terlaksana. Namun, karena kegiatan tersebut bukan merupakan kegiatan pokok dan wajib maka bisa ditinggalkan. Oleh karena itu, untuk menghemat waktu pada siklus kedua, kegiatan 'Iatihan' sebaiknya tidak dilaksanakan. Latihan-latihan soal digabung sekaligus dengan pengerjaan LKM oleh mahasiswa. Hal ini membuat terdapatnya perubahan RPP sebelum plan dengan RPP setelah plan. RPP sebelum plan dibuat kegiatan terpisah antara pengerjaan LKM dengan Latihan. Setelah plan, kedua kegiatan tersebut disatukan dengan harapan bisa menghemat waktu yang ada.

b. Pada siklus pertama, hadiah untuk turnamen yang disediakan dosen kurang banyak, sehingga untuk pertemuan kedua harus disiapkan lebih banyak lagi. Hadiah harus cukup untuk dari awal turnamen hingga akhir. 
c. Dosen harus lebih tegas dalam masalah waktu saat pembelajaran. Jangan sampai diskusi kelompok terlalu lama sehingga menyita waktu untuk kegiatankegiatan pembelajaran lainnya.

d. Materi matematika merupakan materi yang abstrak. Perlu menjelaskan apa kegunaan atau aplikasi materi yang dipelajari dengan kehidupan sehari-hari. Atas dasar ini, pada tahap awal pembelajaran akan dijelaskan terlebih dahulu kegunaan materi dalam kehidupan seperti yang dilakukan pada siklus pertama.

Berdasarkan plan yang telah dibuat, dilaksanakan do pada tanggal 21 September 2018. Pelaksanaan pembelajaran dikelas dapat diringkas sebagai berikut. Pada kegiatan pendahuluan: dosen mengabsen mahasiswa, memberikan apersepsi, memotivasi mahasiswa dengan mengaitkan materi pelajaran dengan kehidupan sehari-hari, dan memberi pengantar tentang materi yang akan dipelajari. Pada kegiatan inti: mahasiswa belajar di kelompok masing-masing membahas materi sementara dosen memberikan bimbingan kepada semua kelompok yang mengalami kendala, perwakilan mahasiswa mempresentasikan hasil pekerjaan kelompoknya, melaksanakan turnamen antar kelompok dengan cara masingmasing kelompok mengutus satu orang secara bergantian sampai turnamen selesai. Pada kegiatan penutup: dosen dan mahasiswa menyimpulkan materi pelajaran, melaksanakan kuis.

Pada pelaksanaan do ini, selain dosen model (peneliti) terdapat juga tiga orang observer yang melakukan pengamatan terhadap aktivitas belajar mahasiswa. Kepada setiap observer diberikan angket yang berisi hasil pengamatan tentang keaktifan belajar dan kerjasama mahasiswa.

Selesai melaksanakan kegiatan do, tim lesson study melaksanakan see pada hari yang sama. Tahap see dimaksudkan untuk mendiskusikan hasil pengamatan yang telah dilakukan oleh para observer. Berikut ini adalah hasil see yang diperoleh:

\section{a. Pelajaran Berharga (Lesson Learn)}

Sebagaimana pada siklus pertama, pada siklus kedua ini perencanaan pembelajaran kembali mengambil peran yang sangat penting. Gagal dalam merencanakan sama dengan merencanakan kegagalan. Berbekal pengalaman pada siklus pertama, perencanaan pada siklus kedua dibuat lebih baik lagi. Secara umum tidak ada perubahan signifikan antara pelaksanaan pembelajaran pada siklus pertama dan kedua. Perencanaan siklus kedua lebih ditekankan pada kekurangan yang ditemukan pada siklus pertama. Kekurangan utama pada siklus utama adalah masalah waktu yang tidak cukup untuk melaksanakan seluruh kegiatan yang sudah direncakan. Upaya yang dilakukan adalah dengan menggabungkan dua kegiatan pembelajaran (pengerjaan LKM dan Latihan Soal) menjadi satu. Hal ini diharapkan mampu menghemat waktu yang ada. Perencanaan yang dilaksanakan pada siklus kedua dapat dikatakan sudah baik dan matang yang ditandai dengan persiapan perangkat pembelajaran yang lengkap (RPP, slide power point, LKM dan soal latihan, soal turnamen, soal kuis, angket penilaian, lembar observasi, penomoran mahasiswa, dan sebagainya). Termasuk juga persiapan hadiah turnamen yang lebih banyak dari sebelumnya. Seluruh tim sepakat bahwa perencanaan yang matang sangat diperlukan untuk kesuksesan pembelajaran di kelas. 
Pada tahap pelaksanaan pembelajaran di kelas, banyak sekali pelajaran yang dapat diambil oleh tim dan dosen model sendiri. Berdasarkan hasil observasi dan refleksi dari para observer dapat disimpulkan beberapa pelajaran berharga yang dapat diambil dari pelaksanaan tahap do di kelas. Pelajaran-pelajaran tersebut sebagian tidak jauh berbeda dari siklus satu. Pertama, dosen model sangat menguasai materi pelajaran. Kedua, dosen model mampu memberikan ilustrasi yang sangat baik tentang konsep matematika kedalam kehidupan nyata. Hal ini membuat mahasiswa lebih mudah memahami materi yang sedang dipelajari. Ketiga, dosen model sangat aktif dalam memberikan bimbingan kepada setiap kelompok secara merata. Keempat, dosen model selalu memberikan support dan pujian kepada mahasiswa. Hal ini penting untuk terus memacu semangat mahasiswa dalam belajar dan memberikan komentar. Kelima, pelaksanaan turnamen mampu meningkatkan keaktifan belajar mahasiswa. Kompetisi antar mahasiswa berhasil membuat mahasiswa berlomba-lomba memahami materi agar mampu memenangkan kompetisi. Keenam, dosen model mampu membuat suasana kelas menjadi santai dengan memberikan lelucon sebagai selingan dalam pembelajaran. Ketujuh, dosen model mampu membuat mahasiswa yang pasif untuk terlibat dalam pelajaran dengan memberikan perhatian khusus kepada mahasiswa pasif tersebut.

\section{b. Catatan tentang kekurangan dan kelebihan dari RPP kegiatan yang dilaksanakan Dosen di kelasnya dikaitkan dengan hasil Lesson Study}

Terdapat kelebihan dan kekurangan dari RPP kegiatan yang telah dilaksanakan dosen model di kelas. Kelebihan dari RPP yang digunakan oleh dosen adalah berhasilnya dosen model dalam mengaktifkan mahasiswa untuk belajar. Konsep belajar yang mengedepankan kolaborasi antar mahasiswa dalam memahami materi membuat mahasiswa berhasil mencapai tujuan pembelajaran yang diinginkan. RPP yang digunakan adalah pembelajaran kolaboratif. Hal ini menumbuhkan kemampuan berkolaborasi antar mahasiswa. Selain itu pembelajaran dengan turnamen mampu membuat mahasiswa saling membantu untuk bisa menjawab soal-soal turnamen, karena hasil kelompok dipengaruhi oleh keberhasilan setiap anggotanya dalam menjawab soal turnamen.

Jika ditinjau dari dosen model sendiri, terdapat beberapa kelebihan dari dosen model saat pelaksanaan pembelajaran, yaitu: dosen model sangat menguasai materi dan mampu memberikan ilustrasi yang baik untuk memahami konsep matematika yang abstrak; dosen model mampu memberikan pendampingan secara merata dan menyeluruh kepada semua mahasiswa; dosen model mampu membawa pembelajaran dengan cara santai dan banyak lelucon sehingga suasana kelas tidak terasa tegang; dosen model sering memberikan pujian kepada mahasiswa yang mau memberikan jawaban atau komentar sehingga mahasiswa termotivasi untuk terus mengikuti pembelajaran dengan baik; dosen model mampu membawa mahasiswa yang pasif menjadi aktif untuk belajar.

Selain kelebihan, terdapat juga kekurangan dari RPP yang digunakan oleh dosen model, yaitu pembelajaran yang mengedepankan aktivitas mahasiswa memerlukan waktu yang relatif lebih lama dibandingkan pembelajaran dengan metode ceramah. Untuk materi yang sangat banyak dengan waktu yang singkat, model pembelajaran yang digunakan kurang cocok. Ditinjau dari dosen model 
sendiri, terdapat kekurangan yaitu bahasa yang digunakan pada slide kurang konsisten. Terdapat kalimat yang menggunakan bahasa inggris dan bahasa indonesia secara bersamaan.

Berikut ini disajikan hasil pengamatan observer tentang keaktifan belajar dan kerjasama mahasiswa.

Tabel 2. Skor Kerjasama dan Keaktifan Belajar Mahasiswa pada Siklus II

\begin{tabular}{cccccc}
\hline \multirow{2}{*}{ Aspek Afektif } & \multicolumn{3}{c}{ Banyak Mahasiswa yang } & Memperoleh Skor & \multirow{2}{*}{ Total } \\
\cline { 2 - 5 } & 1 & 2 & 3 & 4 & \\
\hline Kerjasama & 0 & 3 & 6 & 18 & \multirow{2}{*}{27} \\
\hline Keaktifan Belajar & 0 & 1 & 8 & 18 & \\
\hline
\end{tabular}

Keterangan Skor: $\quad$ 1: Tidak Baik; 2: Kurang Baik; 3: Baik; 4: Sangat Baik

Berdasarkan Tabel 2 dapat dilihat bahwa sebagian besar mahasiswa memiliki skor 3 dan 4 pada masing-masing aspek yang dinilai. Hal ini bermakna bahwa keaktifan belajar dan kerjasama mahasiswa berada pada kategori Baik dan Sangat Baik.

\section{KESIMPULAN DAN SARAN}

Lesson study merupakan salah satu wadah untuk saling berbagi antar sesama dosen dalam rangka meningkatkan kualitas pembelajaran di kelas. Pada pelaksanaan lesson study di penelitian ini terlihat mahasiwa aktif dalam belajar dan memiliki kerjasama yang baik. Pembelajaran yang terpusat kepada mahasiswa efektif dalam meningkatkan kualitas pembelajaran.

\section{DAFTAR PUSTAKA}

Ario, M. 2015. The application of mathematical reasoning and habits of mind through the problem-based learning and discovery learning. Edusentris: Jurnal Ilmu Pendidikan dan Pengajaran. 2 (1) : $34-46$.

Ario, M. 2017. Profil penguasaan materi matematika sekolah mahasiswa pendidikan matematika semester VI. Aksioma. 6 (3) : 385-392.

Barkley, E. E., Cross, K.P., \& Major, C. H. 2012. Collaborative Learning Techniques. Bandung: Nusamedia.

Coenders, F. \& Verhoef, N. 2018. Lesson study: professional development (PD) for beginning and experienced teachers. Professional Development in Education. DOI: 10.1080/194 12527.2018.1430050.

Kemenristekdikti. 2018. Pedoman Program Short Term Training on Lesson Study (STOLS). Jakarta: Kementrian Riset, Teknologi dan Pendidikan Tinggi.

Khasanah, F. 2016. Meningkatkan keaktifan belajar siswa melalui model pembelajaran kooperatif tipe STAD. Jurnal Ilmiah Fakultas Keguruan dan IImu Pendidikan. 18 (2): 48-57.

Maths Development Team. 2017. A Handbook for Lesson Study: Including a Research Lesson Proposal Template. Ireland: Maths Development Team PDST. 
Slavin, R. E. 2012. Cooperative Learning. Bandung: Nusamedia.

UU Nomor 14 Tahun 2005 tentang Guru dan Dosen.

Wagiran. 2006. Meningkatkan keaktifan mahasiswa dan reduksi miskonsepsi melalui pembelajaran konstruktivistik model kooperatif berbantuan modul. Jurnal IImu Pendidikan. 13 (1): 25-32

Yahya, A., Siswandari, \& Sumaryati, S. 2013. upaya meningkatkan keaktifan dan prestasi belajar akuntansi melalui pembelajaran kooperatif tipe NHT dengan media kartu. Jupe UNS. 2 (1) : 169-179.

Zubaidah. 2010. Lesson Study sebagai salah satu model pengembangan profesionalisme guru. Makalah pada Pendidikan dan Pelatihan Nasional dengan tema "Profesionalisme Guru melalui Kegiatan Lesson Study, 22 April 2010" 